\title{
Improving the Mechanical Performance of Shell Precast Concrete Blocks for Coastal Protection Structures of Hydraulic Works
}

\author{
Nguyen Viet Duc \\ Faculty of Civil Engineering \\ Thuyloi University \\ Hanoi, Vietnam \\ ducnv@tlu.edu.vn
}

\begin{abstract}
Although the use of concrete and reinforced concrete for construction has been widespread, more studies are needed on marine structures exposed directly to corrosive environments to prolong their service life. This paper proposes a new type of shell precast concrete block for coastal structures, studying a beam consisting of $15 \mathrm{~mm}$ High-Performance Glass FiberReinforced Concrete (HPGFRC) at the bottom and $45 \mathrm{~mm}$ Traditional Concrete (TC) for the rest of the structure. Steel bar reinforcements were placed at the bottom with a concrete cover of $25 \mathrm{~mm}$ to avoid abrupt failure. The strength classes of HPGFRC and TC were $60 \mathrm{MPa}$ and $30 \mathrm{MPa}$ respectively. A reference beam consisting of TC only was also prepared for comparison. The four-point flexural bending test results showed that the first cracking strength of the proposed beam was $20 \%$ higher, as HPGFRC performed better on tension than TC. Additionally, HPGFRC's maximum strength was $25 \%$ greater than TC's. Furthermore, HPGFRC possessed more durable characteristics such as waterproof grade, abrasion resistance, and shrinkage than TC, promising to protect the reinforcement from the aggressive marine environment and corrosion, prolonging the service life of the structure.
\end{abstract}

Keywords-shell precast concrete block; coastal protection structure; high performance glass fiber-reinforced concrete; marine environment

\section{INTRODUCTION}

Concrete is a versatile material that plays an important role in various construction fields including civil engineering, transportation, irrigation, and marine engineering [1]. Concrete accounts for about $40 \%$ of used construction materials, while concrete structures account for about $60 \%$ of building structures $[1,2]$. However, the Traditional Concrete (TC) has many limitations causing significant impacts on buildings' quality, such as cracks and poor flexural resistance $[3,4]$. The crack propagation affects the bearing capacity of the structure enabling water and harmful components to easily penetrate the concrete by breaking the bonds and damaging the structure in general, especially in marine structures including shell concrete block mats for seacoast protection, as illustrated in Figure 1. Moreover, the chemical composition of seawater can cause corrosive phenomena to both the cement matrix and the reinforcement of marine structures, reducing their service life [5].

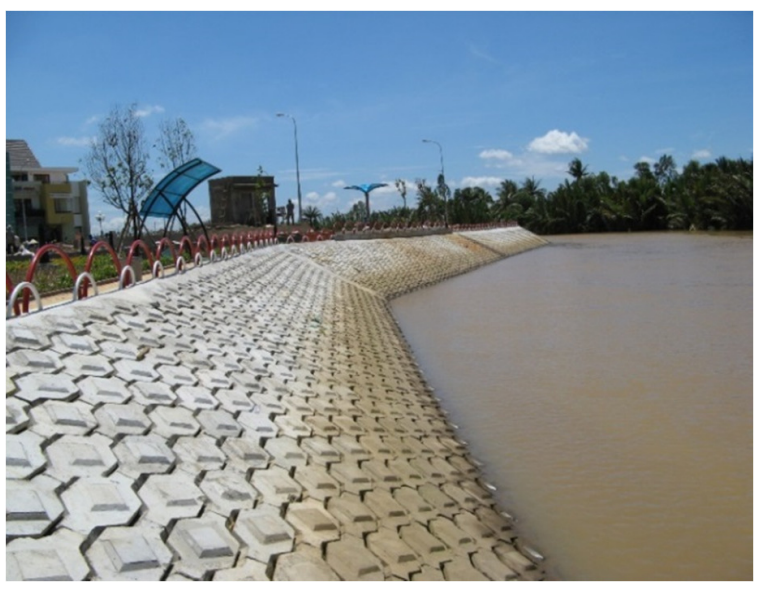

Fig. 1. Shell concrete block mat for seacoast protection.

Reinforced concrete was invented in the middle of the 19th century, and it has been used for marine structures from the late 19th and early 20th century [6]. For instance, in Vietnam, reinforced concrete was put into use by the French since the last years of the 19th century [7, 8]. However, after 1960, the volume of reinforced concrete works in marine environments increased significantly. The actual durability or longevity of reinforced concrete works has been thouroughly studied, and a reinforced concrete structure can be sustainable for over 100 years in non-corrosive environments [9]. However, in an aggressive marine environment, corrosion of reinforcement and concrete leading to cracks may appear after 10-30 years of use [8]. The actual service life of reinforced concrete structures depends on the level of environmental erosion and the quality of materials used, such as concrete's strength, waterproofing grade, corrosion resistance, cement type, additives, reinforcement type, design quality, etc. [10].

Corresponding author: Nguyen Viet Duc, Thuyloi University, 175 Tay Son, 
This paper focuses on improving the mechanical performance of a shell precast concrete block [14] which is used mainly for producing the mat for coastal protection of hydraulic works [11-15]. The constituent materials of a concrete structure exposed to a marine environment should withstand the harsh environment, and glass fiber seems to be an effective option. This paper proposes the concept of a shell precast concrete block having High-Performance Glass FiberReinforced Concrete (HPGFRC) in its partial cover layer, in combination with $\mathrm{TC}$, to protect the concrete matrix, especially reinforcement, from the aggressive environment.

\section{MATERIALS AND METHODS}

\section{A. Constituent Materials}

This study used Ordinary Portland Cement (OPC) type I 42.5, conforming to the European cement standard EN 197-1. Silica Fume (SF) was used as supplementary cementitious material. The physical and the mechanical characteristics of cement and SF are given in Tables I and II, respectively. Due to the current scarcity of natural sand, manufactured sand and crushed stone were used as fine and coarse aggregates for TC and HPGFRC mixes, and their characteristics are shown in Table III. Moreover, a sieve analysis was carried out, and its results are shown in Table IV. Alkali resistant glass fibers, conforming to ASTM C1666, were used for the HPGFRC mix, and their characteristics are shown in Table V. A thirdgeneration polycarboxylate superplasticizer was used. The characteristics of the superplasticizer and water are shown in Table VI.

TABLE I. OPC CHARACTERISTICS

\begin{tabular}{|l|c|c|}
\hline \multicolumn{1}{|c|}{ Parameters } & Units & Test results \\
\hline Specific density & $\mathrm{g} / \mathrm{cm}^{3}$ & 3.13 \\
\hline Bulk density & $\mathrm{g} / \mathrm{cm}^{3}$ & 1.31 \\
\hline Blaine fineness & $\mathrm{cm}^{2} / \mathrm{g}$ & 3730 \\
\hline Consistency & $\%$ & 28.5 \\
\hline Initial setting time & $\mathrm{min}$. & 150 \\
\hline Final setting time & $\mathrm{min}$. & 230 \\
\hline Soundness of cement & $\mathrm{mm}$ & 1 \\
\hline 3 days compressive strength & $\mathrm{N} / \mathrm{mm}^{2}$ & 26.1 \\
\hline 28 days compressive strength & $\mathrm{N} / \mathrm{mm}^{2}$ & 47.6 \\
\hline
\end{tabular}

TABLE II. SF CHARACTERISTICS

\begin{tabular}{|l|c|c|}
\hline \multicolumn{1}{|c|}{ Parameters } & Units & Test results \\
\hline Specific density & $\mathrm{g} / \mathrm{cm}^{3}$ & 2.1 \\
\hline Bulk density & $\mathrm{g} / \mathrm{cm}^{3}$ & 0.93 \\
\hline Loss on ignition & $\%$ & 4.2 \\
\hline Content of $\mathrm{SiO}_{2}$ & $\%$ & 93.5 \\
\hline Content of $\mathrm{Al}_{2} \mathrm{O}_{3}$ & $\%$ & 0.92 \\
\hline Content of $\mathrm{Fe}_{2} \mathrm{O}_{3}$ & $\%$ & 0.52 \\
\hline Content of $\mathrm{SO}_{3}$ & $\%$ & 0.63 \\
\hline Content of $\mathrm{CaO}$ & $\%$ & 1.57 \\
\hline
\end{tabular}

TABLE III. COARSE AND FINE AGGREGATES CHARACTERISTICS

\begin{tabular}{|l|c|c|}
\hline \multicolumn{1}{|c|}{ Parameters } & $\begin{array}{c}\text { Crushed } \\
\text { stone }\end{array}$ & $\begin{array}{c}\text { Manufactured } \\
\text { sand }\end{array}$ \\
\hline Specific density, g/cm ${ }^{3}$ & 2.71 & 2.7 \\
\hline Bulk density, g/cm ${ }^{3}$ & 1.48 & 1.65 \\
\hline Water absorption, \% & 0.9 & 1.9 \\
\hline Clay, silt and dust content, \% & 1.5 & 1.5 \\
\hline Fineness modulus & - & 3.01 \\
\hline
\end{tabular}

TABLE IV. GRADING OF AGGREGATES BY SIEVE ANALYSIS

\begin{tabular}{|c|c|c|}
\hline \multirow{2}{*}{$\begin{array}{c}\text { Sieve } \\
\text { size }\end{array}$} & Crushed stone & Manufactured sand \\
\cline { 2 - 3 } Cumulative \% retained \\
\hline 70 & 0.0 & \\
\hline 40 & 2.9 & \\
\hline 20 & 49.5 & \\
\hline 10 & 80.3 & \\
\hline 5 & 98.0 & 0.0 \\
\hline 2.5 & & 9.5 \\
\hline 1.25 & & 21.8 \\
\hline 0.63 & & 36.6 \\
\hline 0.315 & & 71.2 \\
\hline 0.14 & & 95.4 \\
\hline Pan & 100 & 100 \\
\hline
\end{tabular}

TABLE V. CHARACTERISTICS OF GLASS FIBER

\begin{tabular}{|l|c|c|}
\hline \multicolumn{1}{|c|}{ Glass fiber conforming to ASTM C1666 } & Units & Value \\
\hline Content of $\mathrm{ZrO}_{2}$ & $\%$ & 18.5 \\
\hline Specific density & $\mathrm{g} / \mathrm{cm}^{3}$ & 2.5 \\
\hline Tensile strength & $\mathrm{MPa}$ & 1700 \\
\hline
\end{tabular}

TABLE VI. CHARACTERISTICS OF SUPERPLASTICIZER AND WATER

\begin{tabular}{|l|c|c|}
\hline \multicolumn{1}{|c|}{ Parameter } & Superplasticizer & Water \\
\hline Specific density, $\mathrm{g} / \mathrm{cm}^{3}$ & $1,075 \div 1,095$ & 1 \\
\hline $\mathrm{pH}$ value & $4 \div 6$ & 7 \\
\hline
\end{tabular}

\section{B. Mix Proportions}

Traditional concrete having a strength class of $30 \mathrm{MPa}$ at the age of 28 days was prepared. This strength class was chosen based on the local marketing demands. Two concrete mixes were prepared by using manufactured sand, the TC and the HPGFRC having a strength class of $60 \mathrm{MPa}$. TC was prepared by using the standard mix design method [1], while HPGFRC was prepared considering $[16,17]$, increasing powder content, and reducing coarse aggregate as described in [18-20]. The detailed steps for mixing are described in [21, 22]. The final mix proportions of TC and HPGFRC are presented in Tables VII and VIII, respectively.

TABLE VII. MIX PROPORTION AND FRESH PROPERTIES OF TC

\begin{tabular}{|c|c|c|c|c|}
\hline OPC & Sand & Stone & Water & Slump \\
\hline $\mathrm{kg}$ & $\mathrm{kg}$ & $\mathrm{kg}$ & $\mathrm{L}$ & $\mathrm{Cm}$ \\
\hline 377 & 653 & 1180 & 185 & 6 \\
\hline
\end{tabular}

TABLE VIII. MIX PROPORTION AND FRESH PROPERTIES OF HPGFRC

\begin{tabular}{|c|c|c|c|c|c|c|}
\hline OPC & SF & Sand & $\begin{array}{c}\text { Glass } \\
\text { fiber }\end{array}$ & SP & Water & $\begin{array}{c}\text { Slump } \\
\text { flow }\end{array}$ \\
\hline $\mathrm{kg}$ & $\mathrm{kg}$ & $\mathrm{kg}$ & $\mathrm{kg}$ & $\mathrm{L}$ & $\mathrm{L}$ & $\mathrm{cm}$ \\
\hline 500 & 50 & 1465 & 2.5 & 5.2 & 195 & 20 \\
\hline
\end{tabular}

\section{Specimen Preparation and Test Procedure}

Due to limitations on time and financial expenditure, the shell precast beam was prepared as a preliminary structure concept. The shell beam had $400 \mathrm{~mm}$ length, $100 \mathrm{~mm}$ breadth, and $60 \mathrm{~mm}$ depth. To prevent an abrupt failure due to the smallsized beam, a mild steel bar reinforcement with a $6 \mathrm{~mm}$ diameter was placed inside, two bars were arranged in its tensile section, and the concrete cover was $25 \mathrm{~mm}$. The casting process of the shell precast concrete structure was initiated by 
placing TC into the metallic mold containing the reinforcement, as shown in Figure 2, up to a thickness of $45 \mathrm{~mm}$. This layer was compacted by a hand vibrator. Afterwards, HPGFRC was prepared, as illustrated in Figure 3, and poured above the TC layer with a thickness of $15 \mathrm{~mm}$. Since HPGFRC is a self-compacting concrete, it did not need any vibration. Besides, a beam having only TC was also cast for the comparative study. Three identical specimens were prepared for each type of beam. The specimens were cured for $24 \mathrm{~h}$, as demonstrated in Figure 4. Then, they were removed from the molds, and placed in a climatic chamber with standard curing conditions $\left(T=20 \pm 22^{\circ} \mathrm{C}, \mathrm{RH} \geq 95 \%\right)$. After 28 days, the specimens were taken out from the chamber, as shown in Figure 5.

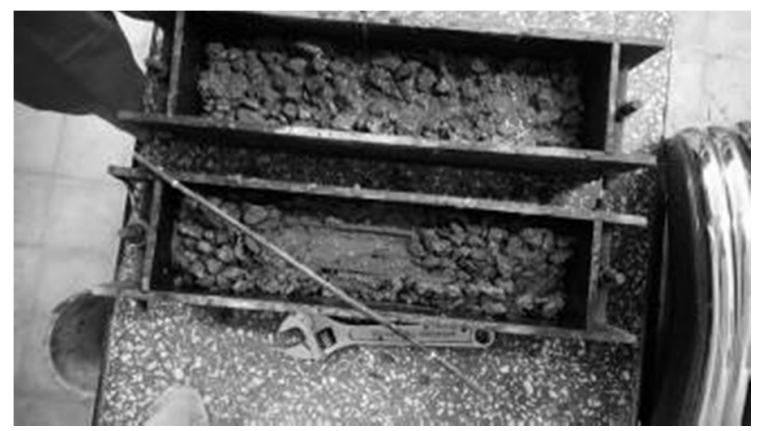

Fig. 2. Casting TC into the mold.

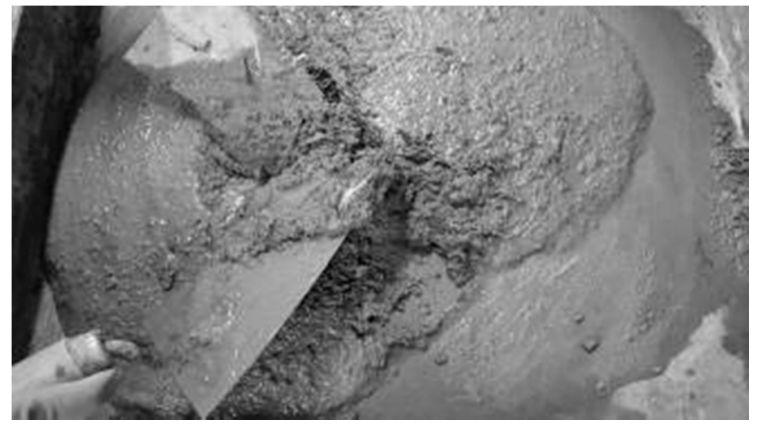

Fig. 3. Preparation of HPGFRC mix.

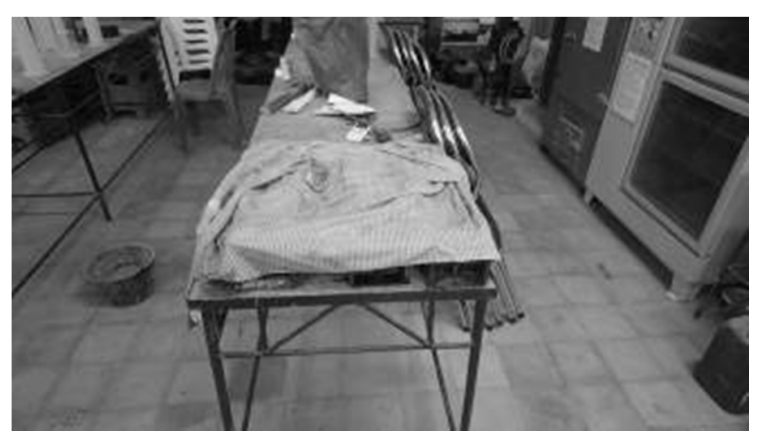

Fig. 4. Specimen curing for the first $24 \mathrm{~h}$.

A four-point bending test was selected. The beam was subjected to the test with a span of $300 \mathrm{~mm}$, and the distance between loading points was $100 \mathrm{~mm}$, as presented in Figure 6 . The test was performed using a hydraulic testing machine, and the load rate was $1 \mathrm{kN}$ per minute. The test was conducted up to beam failure to acquire its maximum loading bearing capacity. The control and the HPGFRC covered beams are shown in Figure 7.

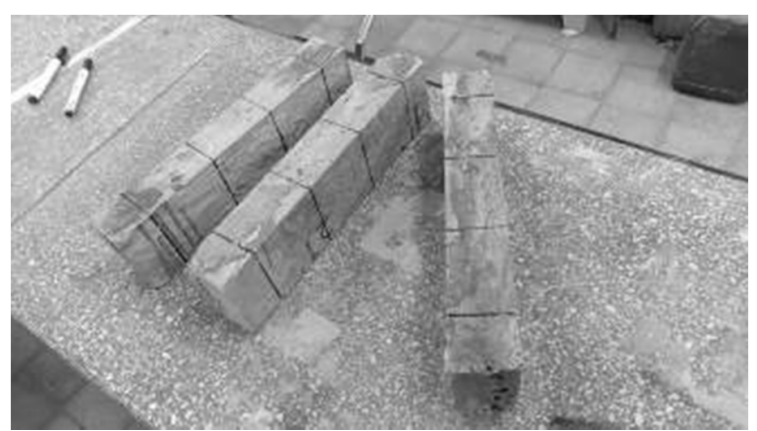

Fig. 5. Specimens after curing of 28 days.

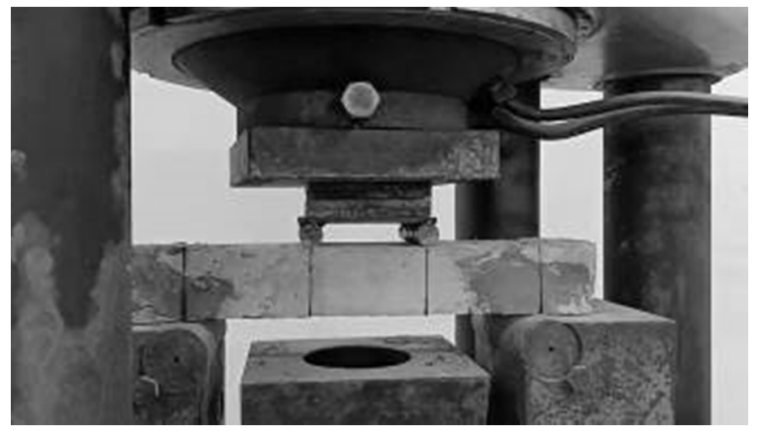

Fig. 6. Four-point bending test.

(a)

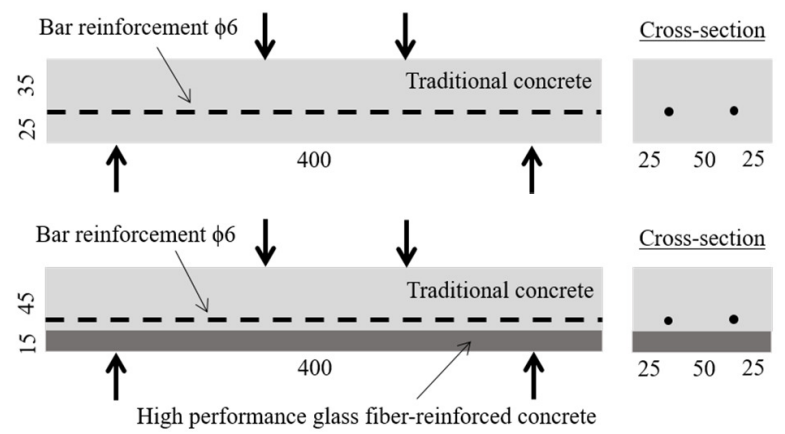

Fig. 7. Beam types: (a) only TC (b) TC with HPGFRC cover.

\section{RESULTS AND DISCUSSION}

\section{A. Hardened Concrete Properties}

Hardened concrete's properties are shown in Table IX. As it can be observed, the TC achieved a concrete strength class of $30 \mathrm{MPa}$, as designed. The compressive strength of HPGFRC was twofold and its flexural strength was almost 2.5 times the TC's. Besides, since the structure was supposed to be used in a marine environment, the durable characteristics of HPGFRC were also determined. The waterproof grade, the abrasion resistance, and the shrinkage of HPGFRC were W12, $0.172 \mathrm{~g} / \mathrm{cm}^{2}$, and $1.196 \mathrm{~mm} / \mathrm{m}$, respectively. Having these hardened properties, according to the TCVN 9139:2012 
standard [23], HPGFRC can be considered as an anti-corrosive material that can be used effectively in marine environments.

TABLE IX. HARDENED PROPERTIES OF TC AND HPGFRC

\begin{tabular}{|c|c|c|c|}
\hline \multicolumn{2}{|c|}{ TC } & \multicolumn{2}{c|}{ HPGFRC } \\
\hline $\begin{array}{c}\text { Compressive } \\
\text { strength (MPa) }\end{array}$ & $\begin{array}{c}\text { Flexural } \\
\text { strength (MPa) }\end{array}$ & $\begin{array}{c}\text { Compressive } \\
\text { strength (MPa) }\end{array}$ & $\begin{array}{c}\text { Flexural } \\
\text { strength (MPa) }\end{array}$ \\
\hline 31.6 & 3.06 & 64.5 & 7.11 \\
\hline
\end{tabular}

\section{B. Flexural Test Performance}

The flexural test results are provided in Table $\mathrm{X}$. The reference beam consists of only $\mathrm{TC}$ and the proposed one consists of both TC and HPGFRC. As it can be observed, the first-cracking strength of the reference beam is almost the same as the flexural strength of TC. This is explained as the beam after the cracking can sustain more load thanks to the steel bar reinforcement. Otherwise, it would fail abruptly due to the material's brittleness. Thus, the maximum flexural strength of the reference beam is almost four-fold the cracking strength.

TABLE $X$. FLEXURAL TEST RESULTS

\begin{tabular}{|c|c|c|c|c|c|}
\hline No & \multicolumn{2}{|c|}{$\begin{array}{c}\text { First cracking strength } \\
\text { (MPa) }\end{array}$} & \multicolumn{2}{|c|}{$\begin{array}{c}\text { Maximum strength } \\
\text { (MPa) }\end{array}$} & Failure mode \\
\hline \multicolumn{6}{|c|}{ Reference beam } \\
\hline 1 & 3.15 & \multirow{3}{*}{3.05} & 11.5 & \multirow{3}{*}{12.0} & Bending \\
\hline 2 & 2.94 & & 12.5 & & Bending \\
\hline 3 & 3.05 & & 11.9 & & Shear \\
\hline \multicolumn{6}{|c|}{ Proposed beam } \\
\hline 1 & 3.63 & \multirow{3}{*}{3.62} & 15.8 & \multirow{3}{*}{15.4} & Bending \\
\hline 2 & 3.55 & & 14.9 & & Shear \\
\hline 3 & 3.69 & & 15.5 & & Bending \\
\hline
\end{tabular}

When the proposed beam was subjected to the bending test, there was a sagging and hogging moment where the bottom layer was under tension and the top layer was under compression. The HPGFRC was at the bottom and the TC was on the top of the beam. Thanks to the significantly-high flexural strength of HPGFRC, compared to the TC, it can be observed that the proposed beams yielded first cracking strength $20 \%$ higher than the reference ones. Besides, the maximum strength of the proposed beam was about $25 \%$ greater than the reference.

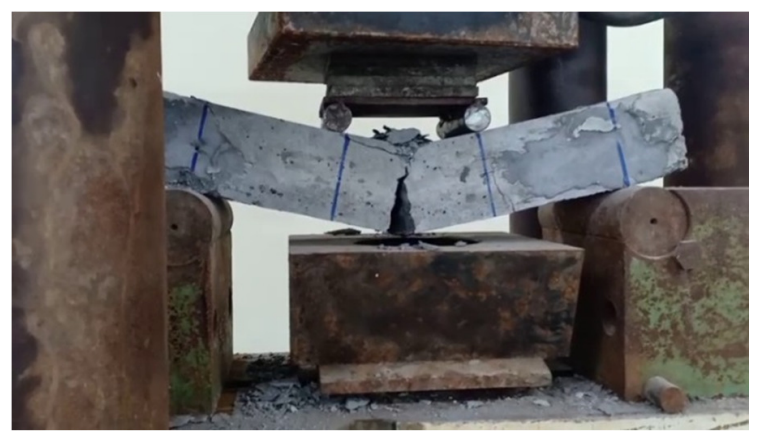

Fig. 8. Failure mode at the middle third due to bending.

During the flexural tests on both the reference and the proposed beams, the first crack propagation always occurred at the middle third, where the beam was exerted the maximum bending moment. However, it was observed that they failed either at the middle third due to bending or at both ends due to shear, as can be observed in Figures 8 and 9. This was mainly due to the role of the longitudinal reinforcement in the tensile section of the beam and the lack of shear reinforcement [6].

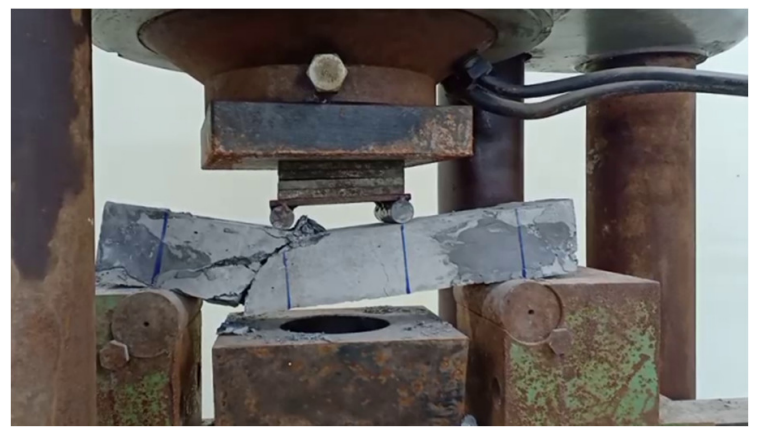

Fig. 9. Failure mode at the left third due to shear.

\section{CONCLUSION}

This paper proposed the use of a High-Performance Glass Fiber-Reinforced Concrete (HPGFRC) to improve the mechanical performance of a shell precast concrete block for coastal protection structures. Shell precast concrete beam specimens were used for experimental tests. Due to better tension response, HPGFRC of strength class $60 \mathrm{MPa}$ was placed at the bottom of the proposed beam to enhance its flexural performance. The first-cracking strength of the proposed beam was $20 \%$ higher than a reference beam consisting totally of Traditional Concrete (TP) with $30 \mathrm{MPa}$ strength class. Moreover, the maximum strength of the proposed beam was $25 \%$ greater than the reference. Furthermore, as HPGFRC has much better durable characteristics than $\mathrm{TC}$, it can protect the reinforcement from corrosion in aggressive marine environments, prolonging the service life of structures.

\section{ACKNOWLEDGMENT}

The author would like to thank Dr. Nguyen Thi Thu Huong for the help and invaluable contribution to the present research.

\section{REFERENCES}

[1] A.M. Neville, Properties of Concrete, 4th ed. London, UK: Pearson Education, 2002.

[2] A. Neville and P.-C. Aïtcin, "High performance concrete-An overview," Materials and Structures, vol. 31, no. 2, pp. 111-117, Mar. 1998, https://doi.org/10.1007/BF02486473.

[3] P. N. Balaguru and S. P. Shah, Fiber-reinforced Cement Composites. New York, NY, USA: McGraw-Hill, 1992.

[4] A. Bentur and S. Mindess, Fibre reinforced cementitious composites. London; New York: Elsevier Applied Science, 1990.

[5] M. A. El-Reedy, Steel-Reinforced Concrete Structures : Assessment and Repair of Corrosion. Boca Raton, FL, USA: CRC Press, 2017.

[6] J. K. Wight and J. G. MacGregor, Reinforced Concrete: Mechanics and Design, 6th ed. Upper Saddle River, N.J, USA: Prentice Hall, 2011.

[7] T. T. H. Nguyen, "Research on solutions to improve the durability of concrete - reinforced concrete of the coastal protection structure of Vietnam," Ph.D. dissertation, Thuyloi University, Hanoi, Vietnam, 2016. 
[8] A. T. Dinh and M. T. Nguyen, Current issue on corrosion of reinforced concrete structure for coastal protection in Vietnam. Vietnam: VAWR, 2012.

[9] O. E. Gjorv, Durability Design of Concrete Structures in Severe Environments, 2nd ed. Boca Raton, FL, USA: CRC Press, 2017.

[10] P.-C. Aïtcin, "Cements of yesterday and today: Concrete of tomorrow," Cement and Concrete Research, vol. 30, no. 9, pp. 1349-1359, Sep. 2000, https://doi.org/10.1016/S0008-8846(00)00365-3.

[11] A. Smyrnis, "Stability of block mats under flow conditions," M.S. thesis, Civil Engineering and Geosciences, Delft University of Technology, Netherlands, 2017.

[12] O. A. Yamini, M. R. Kavianpour, and S. H. Mousavi, "Experimental investigation of parameters affecting the stability of articulated concrete block mattress under wave attack," Applied Ocean Research, vol. 64, pp. 184-202, Mar. 2017, https://doi.org/10.1016/j.apor.2017.03.003.

[13] M. S. Permana, B. Triatmodjo, and N. Yuwono, "Wave-Induced Pressure Distribution on Placed Perforated Revetment Block," Procedia Engineering, vol. 170, pp. 443-450, Jan. 2017, https://doi.org/ 10.1016/j.proeng.2017.03.071.

[14] D. T. Phan, Concrete mat technology TAC-CI for coastal protection. Vietnam: Minh Tac Company, 2012.

[15] T. T. H. Luong, V. T. Bui, Q. V. Vu, and N. K. Pham, "Application of self-compacting concrete on bank protection works on soft ground," Journal of Scientific and Environmental Issues, no. 30, 2010.

[16] Guidelines for Viscosity Modifying Admixtures for Concrete Guidelines for VMA. Farnham, UK: EFNARC / EFCA, 2006.

[17] Specification and Guidelines forSelf-Compacting Concrete. Farnham, UK: EFNARC, 2002.

[18] M. A. Memon, N. A. Memon, A. H. Memon, R. Bhanbhro, and M. H. Lashari, "Flow Assessment of Self-Compacted Concrete incorporating Fly Ash," Engineering, Technology \& Applied Science Research, vol. 10 , no. 2, pp. 5392-5395, Apr. 2020, https://doi.org/ 10.48084/etasr.3283.

[19] N. A. Memon, M. A. Memon, N. A. Lakho, F. A. Memon, M. A. Keerio, and A. N. Memon, "A Review on Self Compacting Concrete with Cementitious Materials and Fibers," Engineering, Technology \& Applied Science Research, vol. 8, no. 3, pp. 2969-2974, Jun. 2018, https://doi.org/10.48084/etasr.2006.

[20] H. Okamura and M. Ouchi, "Self-Compacting Concrete," Journal of Advanced Concrete Technology, vol. 1, no. 1, pp. 5-15, 2003, https://doi.org/10.3151/jact.1.5.

[21] T. L. Ngo, "Study on the implement of fine-grain concrete with glass fiber for rehabilitation of marine structure at Giao Thuy - Nam Dinh province," M.S. thesis, Thuyloi University, Hanoi, Vietnam, 2020.

[22] V. H. Nguyen, "Study on the use of mineral additives and fiber to produce high performance concrete for the coastal area of Nam Dinh $\mathrm{Vu}$, Hai Phong province," M.S. thesis, Thuyloi University, Hanoi, Vietnam, 2018 .

[23] TCVN 9139:2012. Hydraulic Structures - Concrete and reinforced concrete Structures in coastal areas - Technical Specifications. Hanoi, Vietnam: Ministry of Construction, 2012. 